\title{
A Review of the Secondary Metabolites and Biological Activities of Tinospora crispa (Menispermaceae)
}

\author{
Yen Chin Koay* and Faheem Amir \\ School of Chemical Sciences, Universiti Sains Malaysia, Penang 11800, Malaysia \\ *For correspondence: Email: yckoay.86@gmail.com
}

\begin{abstract}
Tinospora crispa Beumee, a herbaceous climber, has been widely used in traditional medicine for treating various ailments such as contusion, septicaemia, fever, fracture, scabies and other tropical ulcers. A wide range of secondary metabolites such as alkaloids, diterpenes, flavones, phenolics, and triterpenes have been isolated, some of which have also shown corresponding biological activities. The current review is an update on the reported pharmacological activities and phytochemical constituents of T. crispa.
\end{abstract}

Keywords: Antioxidant, Alkaloid, Diterpene, Flavone, Triterpene

Tropical Journal of Pharmaceutical Research is indexed by Science Citation Index (SciSearch), Scopus, International Pharmaceutical Abstract, Chemical Abstracts, Embase, Index Copernicus, EBSCO, African Index Medicus, JournalSeek, Journal Citation Reports/Science Edition, Directory of Open Access Journals (DOAJ), African Journal Online, Bioline International, Open-J-Gate and Pharmacy Abstracts

\section{INTRODUCTION}

Tinospora crispa Beumee (Menispermaceae) [syn: T. tuberculata] or known as "akar patawali" or "akar seruntum" in Malaysia and "Borapet" in Thai and "Da ye ruan jin teng" in Chinese, is a herbaceous climbing plant that is widely distributed in South East Asia, particularly in Vietnam, Thailand, Malaysia, Indonesia and India [1-5]. This medicinal herb has been used in the Thai traditional medicine due to its anti-pyretic, antidiabetic, anti-inflammatory, anti-malarial and health maintaining properties [6]. It is also has been used in Chinese traditional medicine for the treatment of contusion, septicaemia, fever, fracture, scabies and other tropical ulcer related disorders [5,7]. Oral administration of the decoction of the stem of the plant is claimed to possess anti-malarial and anti anthelmintic properties whereas decoction of the whole plant has been used as a postpartum remedy and also a traditional remedy for diabetes among the
Malay community [3,8-12]. A poultice of fresh leaves is reported for treatment of wounds and itches $[1,13]$.

\section{PREVIOUS ISOLATION AND CHEMICAL INVESTIGATION}

Phytochemical investigation of the stems of $T$. crispa has led to the isolation of $\mathrm{N}$-trans-feruloyl tyramine and $\mathrm{N}$-cis-feruloyl tyramine from the ethyl acetate fraction as well as a phenolic glucoside, namely, tinotuberide (1) from the butanol fraction [14]. In 1985, a diterpene glucoside, borapetoside $A(2)$, and its aglycone, borapetol A (3) were isolated from the stems of $T$. crispa, followed by the isolation of borapetoside $B(4)$, and its aglycone, borapetol B (5) on the subsequent year [15-16]. The presence of borapetoside $\mathrm{C}-\mathrm{H}$ (6-11) and tinotufolin A-F (12-17) were identified from the stems of the plant [17-20]. 


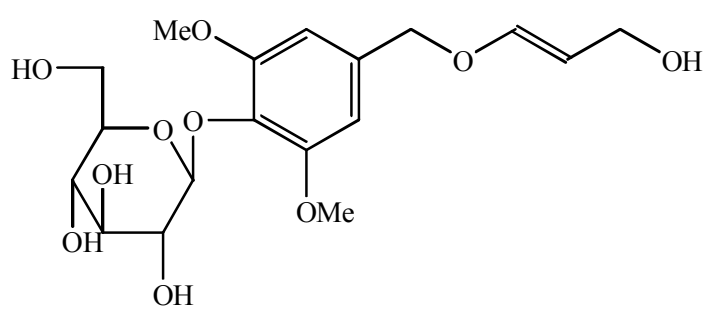

(1)

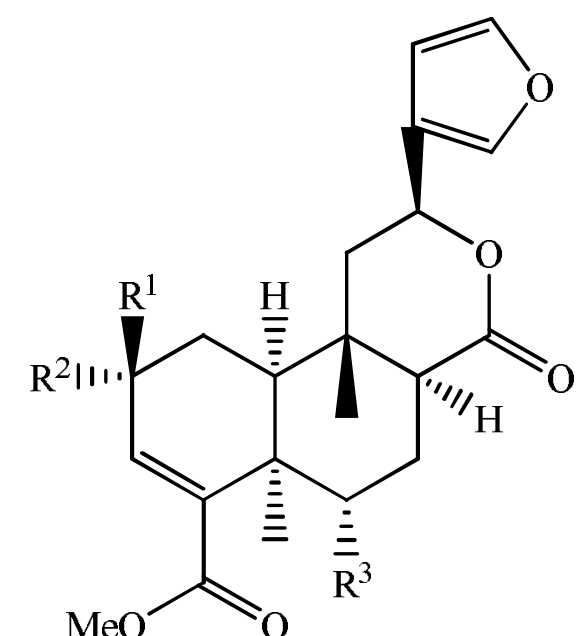

(4) $\mathrm{R}^{1}=\mathrm{H}, \mathrm{R}^{2}=\mathrm{OH}, \mathrm{R}^{3}=-\mathrm{O}-\beta$-D-glc.pyr.

(5) $\mathrm{R}^{1}=\mathrm{H}, \mathrm{R}^{2}=\mathrm{R}^{3}=\mathrm{OH}$

Figure 1: Compound 1 - 6

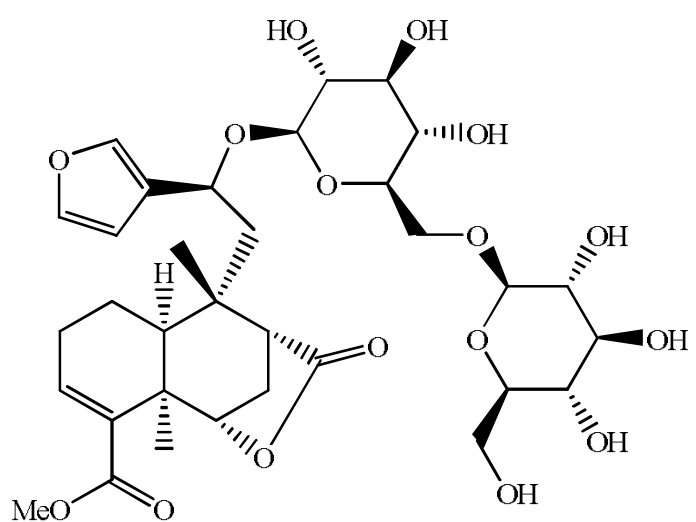

(7)

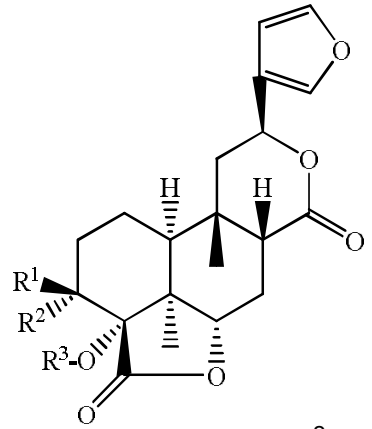

(2) $\mathrm{R}^{1}=-\mathrm{O}-\beta-\mathrm{D}$-glc.pyr., $\mathrm{R}^{2}=\mathrm{R}^{3}=\mathrm{H}$

(3) $\mathrm{R}^{1}=\mathrm{OH}, \mathrm{R}^{2}=\mathrm{R}^{3}=\mathrm{H}$
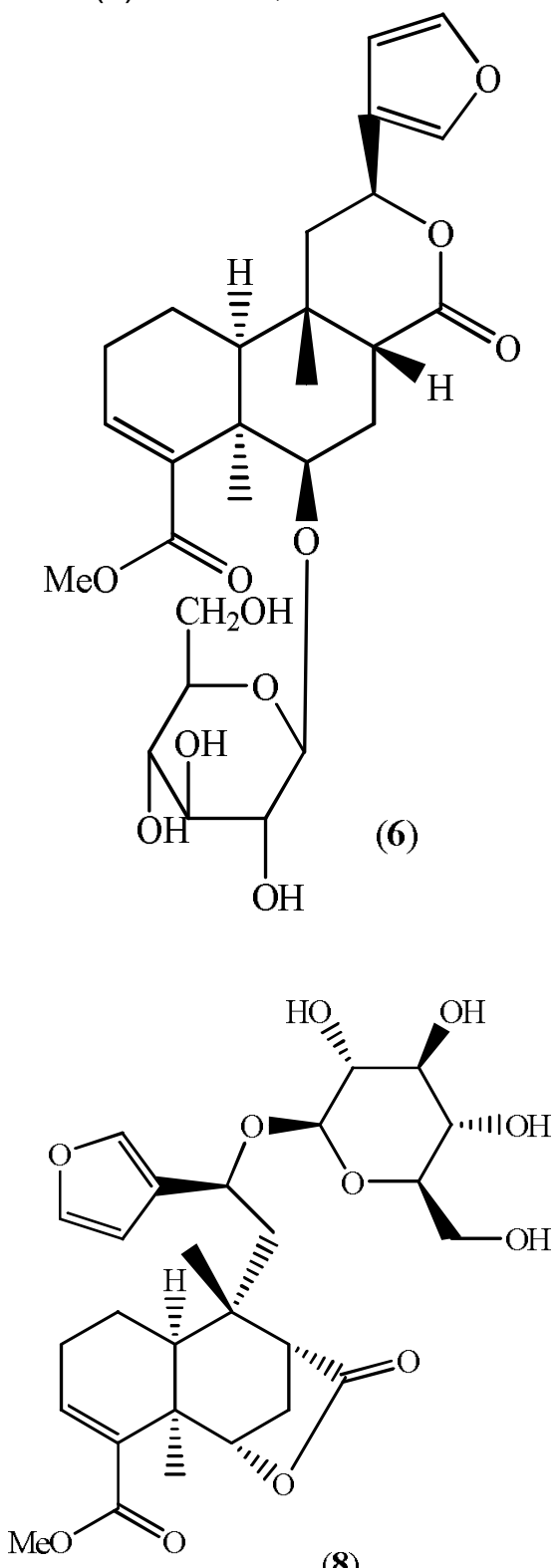

(8) 


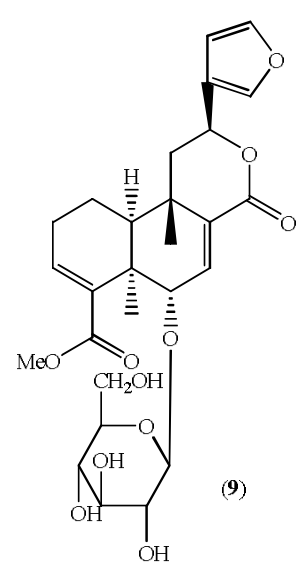

Figure 2: Compounds 7 - 10
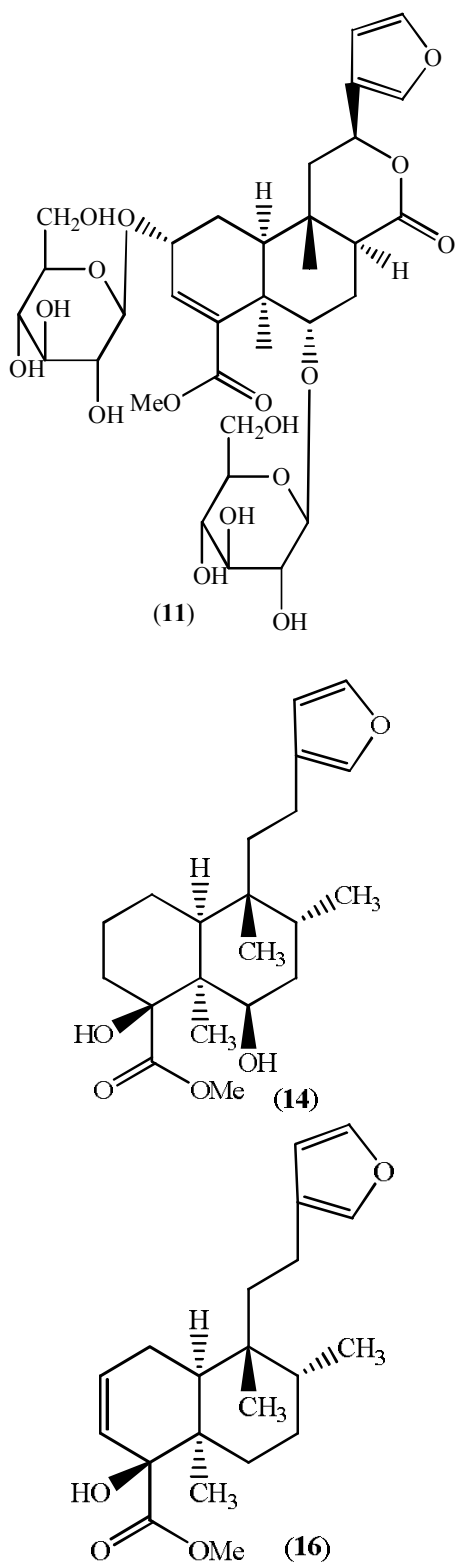

Figure 3: Compounds 11 - 17
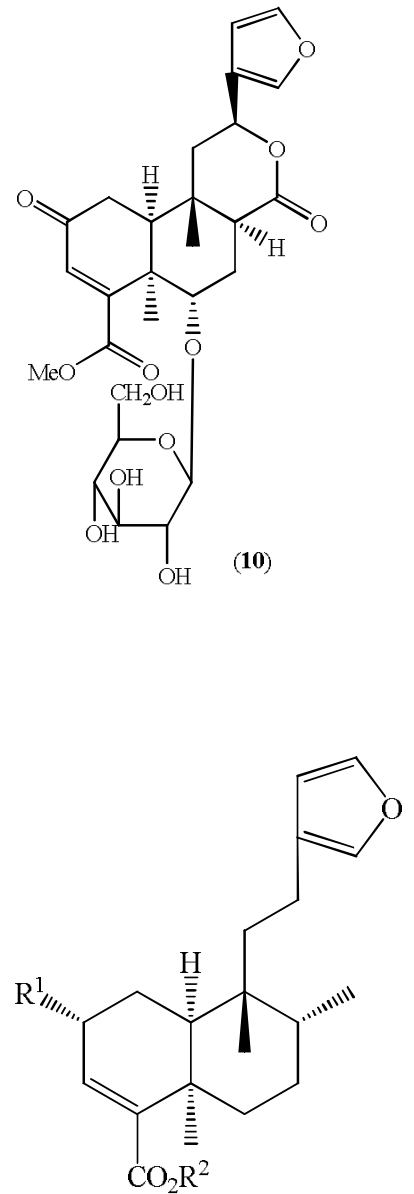

(12) $\mathrm{R}^{1}=\mathrm{OH}, \mathrm{R}^{2}=\mathrm{CH}_{3}$ (13) $\mathrm{R}^{1}=\mathrm{R}^{2}=\mathrm{H}$
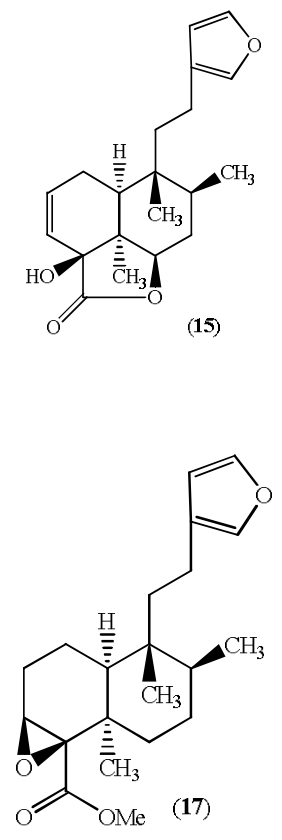
Umi Kalsom \& Noor [21] reported from the stems of $T$. crispa five flavone glycosides which were identified as luteolin 4'-methyl ether 7-glucoside, genkwanin 7-glucoside, luteolin 4'-methyl ether 3'-glucoside, diosmetin and genkwanin.

Lin [22] isolated twelve constituents from the methanol extract of the stems of $T$. crispa, which included $\beta$-sitosterol, stigmasterol, apigenin, $\mathrm{N}$ formylanonaine, $\mathrm{N}$-formylnornuciferine, cycloeucalenol, N-cis-feruloyltyramine, N-transferuloyltyramine, whereas this was the first report of makisteron $\mathrm{C}, \mathrm{N}$-acetylanonaine, $\mathrm{N}$ acetylnornuciferine, $\quad \mathrm{N}$-trans-caffeoyltyramine from $T$. crispa.

The phytochemical investigations of the stems of $T$. crispa afforded one new aporphine alkaloid, $\mathrm{N}$ formylasimilobine 2-O- $\beta$-D-glucopyranoside (18) (Figure 4), along with $\mathrm{N}$-formylasimilobine $2-\mathrm{O}-\beta$ D-glucopyranosyl-( $1 \rightarrow 2)-\beta$-D-glucopyranoside (tinoscorside $\mathrm{A}$ ), $\mathrm{N}$-formylanonaine, $\mathrm{N}$ formyldehydroanonaine, $\mathrm{N}$-formylnomuciferine, $\mathrm{N}$-demethyl-N-formyldehydronornuciferine, magnoflorine, paprazine, $\mathrm{N}$-transferuloyltyramine and cytidine [23].

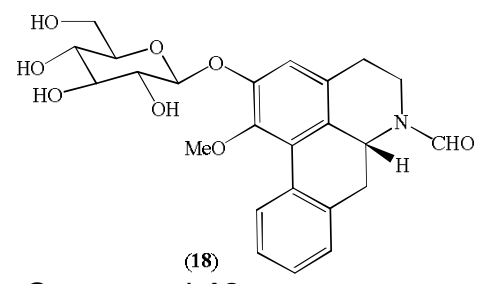

Figure 4: Compound 18

Choudhary et al. [24] also isolated nine new cisclerodane-type furanoditerpenoids, namely, $(2 R, 5 R, 6 R, 8 S, 9 S, 10 S, 12 S)$-15,16-epoxy-2hydroxy-6-O-\{ $\beta$-D-glucopyranosyl-( $1 \rightarrow 6)-\alpha$-Dxylopyranosyl\}-cleroda-3,13(16),14-trien-17,12olid-18-oic acid methyl ester (19) (Figure 5 and $6), \quad(2 R, 5 R, 6 R, 8 R, 9 S, 10 S, 12 S)-15,16$-epoxy-2hydroxy-6-O-( $\beta$-D-glucopyranosyl)-cleroda3,13(16),14-trien-17,12-olid-18-oic acid methyl ester (20), $(5 R, 6 R, 8 S, 9 R, 10 R, 12 S)$-15,16-epoxy2-oxo-6-O-( $\beta$-D-glucopyranosyl)-cleroda3,13(16),14-trien-17,12-olid-18-oic acid methyl ester (21), methyl $(2 R, 7 S, 8 S)-8-[(2 S)-2-(3,4-$ dihydroxy-2,5-dimethoxytetrahydro-3-furanyl)-2hydroxyethyl]-2,8-dimethyl-10-oxo-11oxatricyclo[7.2.1.0]dodec-3-ene-3-carboxylate (22), $\quad(5 R, 6 R, 8 S, 9 R, 10 S, 12 S)-15,16$-epoxy-2oxo-6-O-( $\beta$-D-glucopyranosyl)-cleroda-

3,13(16),14-trien-17,12-olid-18-oic acid methyl ester (23), (2R,5R,6S,9S,10S, 12S)-15,16-epoxy2-hydroxy-6-O-( $\beta$-D-glucopyranosyl)-cleroda3,7,13(16),14-tetraen-17,12-olid-18-oic acid methyl ester (24), (5R,6S,9S,10S,12S)-15,16epoxy-2-oxo-6-O-( $\beta$-D-glucopyranosyl)-cleroda3,7,13(16),14-tetraen-17,12-olid-18-oic acid methyl

ester

(25), $(3 R, 4 R, 5 R, 6 S, 8 R, 9 S, 10 S, 12 S)$-15,16-epoxy-3,4epoxy-6-O-( $\beta$-D-glucopyranosyl)-cleroda-

3,13(16),14-trien-17,12-olid-18-oic acid methyl ester (26) and (1R,4S,5R,8S,9R,10S,12S)-15,16epoxy-4-O-( $\beta$-D-glucopyranosyl)-cleroda-

2,13(16), 14-triene-17(12),18(1)-diolide (27).

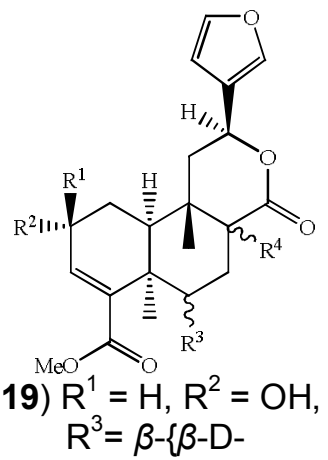

glucopyranosyl-(1-6)- $\alpha$ -

D-xylopyranose $\}, \mathrm{R}^{4}=\alpha$ $\mathrm{H}$

(20) $\mathrm{R}^{1}=\mathrm{H}, \mathrm{R}^{2}=\mathrm{OH}$, $\mathrm{R}^{3}=\beta-(\beta-\mathrm{D}-$

glucopyranosyl), $R^{4}=\beta$ $\mathrm{H}$
(21) $\mathrm{R}^{1}=\mathrm{R}^{2}=\mathrm{C}=\mathrm{O}, \mathrm{R}^{3}=$
$\beta-(\beta-\mathrm{D}$-glucopyranosyl),
$\mathrm{R}^{4}=\alpha-\mathrm{H}$

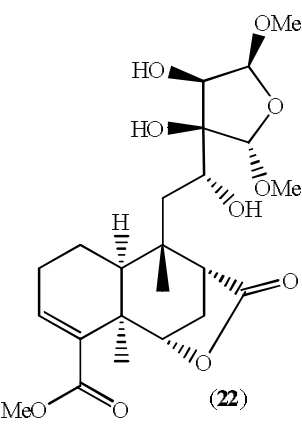


Chung [25] revealed the presence of forty phytochemical constituents, namely, borapetoside $A$, borapetoside $B$, borapetoside $C$, borapetoside $D$, borapetoside $E$, borapetoside $F$, (2R,5R,6R,8R,9S,10S,12S)-15,16-epoxy-2hydroxy-6-O-( $\beta$-D-glucopyranosyl)-cleroda3,13(16),14-trien-17,12-olid-18-oic acid methyl ester, $\quad(2 \mathrm{R}, 5 \mathrm{R}, 6 \mathrm{~S}, 9 \mathrm{~S}, 10 \mathrm{~S}, 12 \mathrm{~S})-15,16$-epoxy-2hydroxy-6-O-( $\beta$-D-glucopyranosyl)-cleroda-

3,7,13(16),14-tetraen-17,12-olid-18-oic acid methyl ester, (1R,4S,5R,8S,9R,10S,12S)-15,16epoxy-4-O-( $\beta$-D-glucopyranosyl)-cleroda-

2,13(16),14-triene-17(12),18(1)-diolide, tinocrisposide $A$, tinocrisposide $B$, tinocrisposide $C$, tinocrisposide $D$, rumphioside $A$, rumphioside $B$, rumphioside $C$, rumphioside $F$, rumphioside $I$, borapetol $A$, borapetol $B$, borapetic acid $A$, borapetic acid $\mathrm{B}$, borapetic acid $\mathrm{C}, \mathrm{N}$ formylanonaine, N-formylnornuciferine, Nacetylanonaine, $\mathrm{N}$-acetylnornuciferine, $\mathrm{N}$ demethyl-N-formyldehydronuciferine, $\quad \mathrm{N}-2,3,9-$ methyltetrahydrocolumbamine, N-trans-feruloyltyramine, N-cis-feruloyltyramine, N-transcaffeoyltyramine, paprazine, trans-isoferulic acid, acantrifoside E, 3-hydroy-3-methylglutarylacantrifoside $E$, apigenin, secoisolariciresinol, syringaresinol and cycloeucalenol from the methanol extract of $T$. crispa.

\section{PHYTOCHEMICAL INVESTIGATIONS BASED ON BIO - ACTIVITY}

Cavin et al [26] examined the dichloromethane extract of $T$. crispa and indicated the presence of vanillin, syringin, $\mathrm{N}$-formylannonain, $\mathrm{N}$ formylnornuciferin, borapetosides $\mathrm{B}, \mathrm{C}$ and $\mathrm{F}, \mathrm{N}$ cis-feruloyltyramine, $\mathrm{N}$-trans-feruloyltyramine and secoisolariciresinol. Antioxidant and free-radical scavenging activity of $\mathrm{N}$-cis-feruloyltyramine, $\mathrm{N}$ trans-feruloyltyramine and secoisolariciresinol were found to exhibit higher antioxidative potency than the synthetic antioxidant butylhydroxytoluene (BHT).

The presence of two triterpenes, namely, cycloeucalenol and cycloeucalenone were reported for the first time from the chloroform extracts of the dried stems of $T$. crispa. Both of the isolated triterpenes further indicated mild cardiotonic effects, where cycloeucalenol showed slight increased in the right atrial contraction and initial reduction followed by $10 \%$ of sustained reduction on the left atria of the rat in vitro meanwhile cycloeucalenone, showed slight change on the right and left atrial contraction [27].

Imphanban et al [28] isolated an aporphine alkaloid, namely, (-)-N-formylnornuciferine from the stems of $T$. crispa, which revealed in vitro cardiotonic activity. Synthesis of the mixture, ( \pm )$\mathrm{N}$-formylnornuciferine, via palladium-catalyzed coupling reaction, indicated significant reduction in the force of contraction and the heart rate.

Bioassay guided fractionation of the n-butanol extract of the stems of $T$. crispa has resulted the isolation of five pharmacologically active compounds which were identified as salsolinol, adenosine, uridine, tyramine and higenamine, along with seven non-active compounds, namely, syringing, borapetoside $A, B, D$ and $E$, adenine and litcubinine. The investigation of the pharmacologically active compounds on mechanisms of action on the blood pressure and heart rate in anesthetized, normal and reserpinized rats in vivo were carried out. The results of investigation further suggested that the cardiovascular responses of the anesthetized rats towards salsolinol, tyramine and higenamine were acted through the stimulation of the adrenoreceptors, whereby uridine and adenosine acted via the purinergic adenosine $A_{2}$ and $P_{2}$ receptors to decrease blood pressure with a transient decrease of heart rate followed by an increase [29].

Lam et al [30] isolated three new diterpenoids, namely, 2-O-lactoylborapetoside B (28) (Figure 7), 6'-O-lactoylborapetoside B (29) and tinocrispol A (30), along with nine known diterpenoids, identified as borapetosides A-F, borapetols $A$ and $B$ and columbin from the ethanolic extract of $T$. crispa vines. Borapetosides $A$ and $C$ were found to lower the plasma glucose levels in normal and streptozotocin-induced type 1 diabetic mice upon examination on the in vivo hypoglycemic activities.

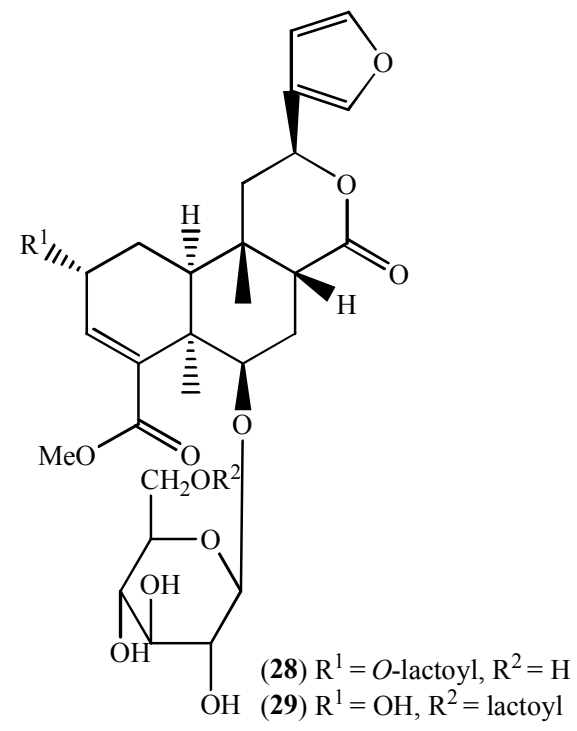

Trop J Pharm Res, August 2013;12 (4): 645 
<smiles>COC(=O)C1=C[C@@H](c2ccccc2)C[C@]2(C)[C@]1(C)C=C[C@@]1(O)C(=O)O[C@@H](c3ccoc3)C[C@]12C</smiles>

Figure 7: Compounds $\mathbf{2 8}-\mathbf{3 0}$

\section{BIOLOGICAL ACTIVITIES AND FORMULATIONS}

\section{Antibacterial activity}

The antibacterial studies conducted by Al-alusi et al. [31] has shown a promising antibacterial activity of $T$. crispa extracts against the Methicillin-resistant Staphylococcus aureus (MRSA) as compared to the control, vancomycin.

\section{Antifilarial activity}

The aqueous extract of dried stems of $T$. crispa, assessed for in vitro antifilarial effects, has indicated moderate activity against the adult worms of subperiodic Brugia malayi after the aqueous extract of Xylocarpus granatum and dried leaves of Andrographis paniculata, whereby the value of relative movability values were used as a measure of the antifilarial activity [32]. The aqueous extract of $T$. crispa was found to exhibit microfilaricidal activity which the microfilaricidal activity was investigated based upon direct observation of the microfilarial motility [33].

\section{Antihyperglycaemic activity}

The study of Noor and Ashcroft [34] indicated that the orally administrated extract of $T$. crispa exhibited significant antihyperglycaemic effect. The extract may consist of compounds which initiated the insulin secretion through the modulation of $\beta$-cell $\mathrm{Ca}^{2+}$ concentration. Thus, it can be further used as an antidiabetic agent for the treatment of type II diabetes.

\section{Anti-nitric oxide (Anti-NO) activity}

The aqueous extract of $T$. crispa was found to suppress nitric oxide oxide production by lipopolysaccharide-stimulated murine macrophages. Significant inhibitory activity against the NO level and inducible NO synthase was showed by ethyl acetate layer when partitioned with the aqueous extract. Both subfraction of E-3 and N-trans-feruloyltyramine displayed strong anti-NO activity $[35,36]$

\section{Antioxidant activity}

Based on DPPH, FRAP and TBA tests, the aqueous crude extract of $T$. crispa stem was found to exhibit high antioxidant activity and its antioxidative potency is comparable to the established antioxidants, such as BHT and vitamin $C[37,38]$. The antioxidant activity carried by Froemming [39] indicated that the methanol extract of $T$. crispa showed the highest antioxidant activity which was determined by measuring total flavonoid content, total phenolic content and DPPH free radical scavenging activity.

\section{Antiparasitic activity}

Rungruang \& Boonmars [40] studied the in vivo antimalarial effect of the crude extract of

$T$. crispa and the mice administrated of the extract with a dose of $80 \mathrm{mg} / \mathrm{kg}$ once a day were found to exhibit promising inhibitory activity against the parasite, Plasmodium yoelii.

\section{Anti-proliferative activity}

The result of anti-proliferative activity of the aqueous crude extract of $T$. crispa stem indicated a significant cytotoxic effect on certain human cancer cell lines such as MCF-7 (IC ${ }_{50}: 107$ $\mu \mathrm{g} / \mathrm{mL})$, HeLa $\left(\mathrm{IC}_{50}: 165 \mu \mathrm{g} / \mathrm{mL}\right)$, Caov-3 (IC ${ }_{50}$ : $100 \mu \mathrm{g} / \mathrm{mL})$ and HepG2 $\left(\mathrm{IC}_{50}: 165 \mu \mathrm{g} / \mathrm{mL}\right)$ [37] as compared to cisplatin and tamoxifen, the human anticancer drugs. Froemming [39] reported the methanolic extract of $T$. crispa displayed a dosedependent cytotoxic effect on MDA-MB-231 and MCF-7 cancer cell lines with an $\mathrm{IC}_{50}$ value of 44.8 and $33.8 \mu \mathrm{g} / \mathrm{mL}$, respectively.

\section{Atherosclerosis inhibitory activity}

The study conducted by Amom et al [41] revealed $T$. crispa stem aqueous extract delays the development of atherosclerosis by suppressing the total cholesterol, triglycerides, low density lipoprotein levels but showed a significant increased level of high density lipoprotein.

\section{Thioacetamide-induced hepatotoxicity}

Oral administration of ethanolic extract of $T$. crispa twice daily for 8 weeks at a dose of 100 $\mathrm{mg} / \mathrm{kg}$ and $200 \mathrm{mg} / \mathrm{kg}$ was found to possess a significant effect on the thioacetamide-induced liver cirrhosis in rats [42]. 


\section{Cardio-protective activity}

The cardio-protective studies on the n-butanol extract of $T$. crispa demonstrated the presence of at least three different cardiovascular-active components which acted through (1) $\beta_{2^{-}}$ adrenergic receptors to cause a decrease in blood pressure, and $\beta_{1}$ - and $\beta_{2}$-adrenergic receptors to cause an increase in heart rate, (2) a-adrenergic receptors to cause an increase in blood pressure and heart rate, and (3) a nonadrenergic and noncholinergic pathway to cause a decrease in MAP and heart rate [43].

\section{Central analgesic activity}

The dried extract of stem of $T$. crispa exhibited promising central analgesic activity at a dosage of $666 \mathrm{~mL}$ [44].

\section{Cytochrome inhibitory activities}

Usia et al [45] studied the inhibitory effects of 30 indonesian medicinal plants against cytochrome P450 3A4 (CYP3A4) and CYP2D6 with a radiometric assay and suggested that $T$. crispa, showed inhibitory activity over $70 \%$ on the metabolism mediated by CYP3A4. Subehan et al [46] showed that among 30 other plants in an inhibitory assay of cytochrome P450 3A4 (CYP3A4) and CYP2D6 via erythromycin $\mathrm{N}$ demethylation and dextromethorphan $O$ demethylation activities in human liver microsomes that $T$. crispa, exhibited more than $30 \%$ increase of CYP3A4 inhibition.

\section{Hypoglycemic effects}

Oral administration of $T$. crispa extract was found to display potent in vitro insulinotropic activity in the human and rat islets and HIT-T15 B cells [47]. Sriyapai et al [48] examined the T. crispa dry powder for hypoglycemic effect on the patients with metabolic syndrome. Administrated of $250 \mathrm{mg} \mathrm{T}$. crispa dry powder twice a day for 2 months was proven to decrease fasting blood glucose significantly from the baseline. The study by Noipha and Ninla-aesong [49] indicated that the extract of $T$. crispa enhances the glucose uptake by in L6 myotubes which was associated to the increased levels of GLUT1 transporter, AMPKa and PPARy transcript.

\section{CONCLUSION}

A large number of secondary metabolites and biological activities have been reported from $T$. crispa; however, it would be valuable to conduct bioassay-guided phytochemical studies on this plant in order to isolate new biologically important secondary metabolites.

\section{ACKNOWLEDGMENT}

The authors are thankful to Universiti Sains Malaysia for the award of postgraduate fellowships to Amer H Khan.

\section{REFERENCES}

1. Burkill I. A dictionary ofthe economic products of the Malay Peninsula: Vol II. Ministry of Agriculture and Co-operatives, Kuala Lumpur, 1966; pp 2202-2205.

2. Perry LM. Medicinal plants of East and Southeast Asia: Attributed Properties and Uses. The MIT Press, Cambridge, England, 1980; pp 620.

3. Hirschhorn $\mathrm{HH}$. Botanical remedies of the former dutch east indies (Indonesia). Part II: dicotyledones up to and including Leguminosae. Journal of Ethnopharmacology, 1983; 8(1): 65-96.

4. Pathak AK, Jain DC, Sharma RP. Chemistry and biological activities of the Genera Tinospora. Pharmaceutical Biology, 1995; 33(4): 277287.

5. Li S, Long C, Liu F, Lee S, Guo Q, Li R, Liu Y. Herbs for medicinal baths among the traditional Yao communities of China. Journal of Ethnopharmacology, 2006; 108(1): 59-67.

6. Kongsaktrakoon $B$, Temsiririrkkul $R$, Suvitayavat $W$, Nakornchai S, Wongkrajang Y. The antipyretic effect of Tinospora crispa Mier ex Hook. F. \& Thoms. Journal of Pharmaceutical Sciences, 1984; 21(1): 1-6.

7. Farnsworth NR, Bunyaphatsara N. Tinospora crispa. In Thai Medicinal Plants. Prachachon Co., Thailand, 1992; pp 244-245.

8. Gimlette JD, Burkill IH. The medical book of Malayan medicine. Gardens' Bulletin, Straits Settlements 6, ,1930; pp 323-474.

9. Yokozawa T, Wang TS, Chen CP, Hattori M. Tinospora tuberculata suppresses nitric oxide synthesis in mouse macrophages. Biological \& Pharmaceutical Bulletin, 1999; 22(12): 13061309.

10. Al-Adhroey AH, Nor ZM, Al-Mekhlafi HM, Mahmud R. Ethnobotanical study on some Malaysian anti-malarial plants: A community based survey. Journal of Ethnopharmacology, 2010; 132(1): 362-364.

11. Ong HC, Nordiana M. Malay ethno-medico botany in Machang, Kelantan, Malaysia. Fitoterapia, 1999; 70(5): 502-513.

12. Roosita K, Kusharto CM, Sekiyama M, Fachrurozi $Y$, Ohtsuka R. Medicinal plants used by the villagers of a Sundanese community in West Java, Indonesia. Journal of Ethnopharmacology, 2008; 115(1): 72-81.

13. Quisumbing EA. Medicinal plants of the Philippines. Katha Publishing Co., Inc.,,Quezon City, Philippines, 1978; pp 1262.

14. Fukuda $N$, Yonemitsu $M$, Kimura $T$. Studies on the constituents of the stems of Tinospora tuberculata Beumee. I. N-trans-and N-cisferuloyl tyramine, and a new phenolic glucoside, tinotuberide. Chemical \& Pharmaceutical Bulletin, 1983; 31(1): 156161.

15. Fukuda N, Yonemitsu M, Kimura T. Studies on the constituents of the stems of Tinospora tuberculata Beumee, III.: New diterpenoids, 
borapetoside $B$ and borapetol B. Chemical \& Pharmaceutical Bulletin, 1986; 34(7): 28682872.

16. Fukuda N, Yonemitsu M, Kimura $T$. Studies on the constituents of the stems of Tinospora tuberculata Beumee. II. New diterpenoids, borapetoside $A$ and borapetol $A$. Chemical \& Pharmaceutical Bulletin, 1985; 33(10): 44384444.

17. Fukuda $N$, Nakamura $M$, Yonemitsu $M$, Kimura $T$, Isobe $R$, Komori $T$. Studies on the constituents of the leaves of Tinospora tuberculata, I.Isolation and structure elucidation of two new furanoid diterpenes, tinotufolin $A$ and $B$. Liebigs Annalen der Chemie, 1993; 1993(3): 325-327.

18. Fukuda N, Yonemitsu M, Kimura T. Studies on the constituents of the stems of Tinospora tuberculata, IV. Isolation and structure elucidation of the five new furanoid diterpene glycosides borapetoside $C-G$. Liebigs Annalen der Chemie, 1993; 1993(5): 491495.

19. Fukuda N, Yonemitsu M, Kimura $T$, Isobe R, Komori $T$. Studies on the constituents of the leaves of Tinospora tuberculata, II. Isolation and structure elucidation of four new furanoid diterpenes, tinotufolin C-F. Liebigs Annalen der Chemie, 1994; 1994(7): 755-757.

20. Fukuda N, Yonemitsu M, Kimura T. Studies on the constituents of the stems of Tinospora tuberculata, $V$. Isolation and structure elucidation of the new furanoid diterpene glucoside borapetoside H. Liebigs Annalen, 1995; 1995(9): 1689-1691.

21. Umi Kalsom $Y$, Noor $H$. Flavone O-glycosides from Tinospora crispa. Fitoterapia, 1995; 66(3): 280.

22. Lin YH, China Medical University, 2009.

23. Choudhary MI, Ismail M, Ali Z, Shaari K, Lajis NH. Alkaloidal constituents of Tinospora crispa. Natural Product Communications, 2010; 5(11): 1747-1750.

24. Choudhary MI, Ismail M, Shaari K, Abbaskhan A, Sattar SA, Lajis NH. cis-Clerodane-type furanoditerpenoids from Tinospora crispa. Journal of Natural Products, 2010; 73(4): 541-547.

25. Chung SY, China Medical University, 2011.

26. Cavin A, Hostettmann K, Dyatmyko W, Potterat O. Antioxidant and lipophilic constituents of Tinosproa crispa. Planta Medica, 1998; 64(5): 393-396.

27. Kongkathip N, Dhumma-upakorn $P$, Kongkathip $B$, Chawananoraset $K$, Sangchomkaeo $P$, Hatthakitpanichakul S. Study on cardiac contractility of cycloeucalenol and cycloeucalenone isolated from Tinospora crispa. Journal of Ethnopharmacology, 2002; 83(1-2): 95-99.

28. Imphanban K, Kongkathip N, Dhumma-upakorn $P$, Mesripong R, Kongkathip B. Synthesis of $N$ formylnornuciferine with cardiotonic activity. Natural Sciences, 2009; 43(4): 738-744.

29. Praman S, Mulvany MJ, Williams DE, Andersen RJ, Jansakul C. Hypotensive and cardiochronotropic constituents of Tinospora crispa and mechanisms of action on the cardiovascular system in anesthetized rats. Journal of Ethnopharmacology, 2012; 2012(1-13.

30. Lam SH, Ruan CT, Hsieh PH, Su MJ, Lee SS. Hypoglycemic diterpenoids from Tinospora crispa. Journal of Natural Products, 2012;
31. Al-alusi NT, Kadir FA, Ismail S, Abdullah MA. In vitro interaction of combined plants: Tinospora crispa and Swietenia mahagoni against Methicillin-resistant Staphylococcus aureus (MRSA). African Journal of Microbiology Research, 2010; 4(21): 2309-2312.

32. Zaridah MZ, Idid SZ, Wan Omar A, Khozirah S. In vitro antifilarial effects of three plant species against adult worms of subperiodic Brugia malayi. Journal of Ethnopharmacology, 2001; 78(1): 79-84.

33. Merawin $L T$, Arifah AK, Sani RA, Somchit MN, Zuraini A, Ganabadi S, Zakaria ZA. Screening of microfilaricidal effects of plant extracts against Dirofilaria immitis. Research in Veterinary Science, 2010; 88(1): 142-147.

34. Noor H, Ashcroft SJH. Pharmacological characterisation of the antihyperglycaemic properties of Tinospora crispa extract. Journal of Ethnopharmacology, 1998; 62(1): 7-13.

35. Yokozawa $T$, Tanaka $T$, Kimura $T$. Examination of the nitric oxide production-suppressing component in Tinospora tuberculata. Biological \& Pharmaceutical Bulletin, 2001; 24(10): 1153-1156.

36. Yokozawa $T$, Wang TS, Chen $C P$, Hattori M. Inhibition of nitric oxide release by an aqueous extract of Tinospora tuberculata. Phytotherapy Research, 2000; 14(1): 51-53.

37. Amom Z, Md Akim A, Nik Hassan MK, Ibrahim N, Moklas M, Aris M, Bahari $H$, Fazil MNF, Fairuz Azman K, Kadir A. Biological properties of Tinospora crispa (Akar Patawali) and Its antiproliferative activities on selected human cancer cell lines. Malaysian Journal of Nutrition, 2008; 14(2): 173-187.

38. Zulkhairi A, Hasnah B, Sakinah I, Nur Amalina I, Zamree MS, Mohd Shahidan A. Nutritional composition, antioxidant ability and flavonoid content of Tinospora crispa stem. . Advances in Natural and Applied Sciences, 2009; 3(1): 88-94.

39. Froemming GA. Anti-proliperative and antioxidant effects of Tinospora crispa (Batawali). Biomedical Research, 2011; 22(1): 57-62.

40. Rungruang $T$, Boonmars $T$. In vivo antiparasitic activity of the Thai traditional medicine plantTinospora crispa-against plasmodium Yoelii. Southeast Asian Journal of Tropical Medicine and Public Health, 2009; 40(5): 898-900.

41. Amom Z, Azman KF, Ismail NORA, Shah Z, Arshad MSM. An aqueous extract of Tinospora cispa possesses antioxidative properties and reduces atherosclerosis in hypercholesterolemic-induced rabbits. Journal of Food Biochemistry, 2011; 35(4): 1083-1098.

42. Kadir FA, Othman $F$, Abdulla MA, Hussan $F$, Hassandarvish P. Effect of Tinospora crispa on thioacetamide-induced liver cirrhosis in rats. Indian Journal of Pharmacology, 2011; 43(1): 64

43. Praman S, Mulvany MJ, Allenbach $Y$, Marston A, Hostettmann $K$, Sirirugsa $P$, Jansakul $C$. Effects of an n-butanol extract from the stem of Tinospora crispa on blood pressure and heart rate in anesthetized rats. Journal of Ethnopharmacology, 2011; 133(2): 675-686.

44. Almeida RN, Navarro DS, Barbosa-Filho JM. Plants with central analgesic activity. Phytomedicine, 2001; 8(4): 310-322.

45. Usia $T$, Iwata $H$, Hiratsuka $A$, Watabe $T$, Kadota $S$, Tezuka Y. CYP3A4 and CYP2D6 inhibitory activities of Indonesian medicinal plants. Phytomedicine, 2006; 13(1-2): 67-73. 
46. Subehan Usia $T$, Iwata $H$, Kadota $S$, Tezuka $Y$. Mechanism-based inhibition of CYP $3 A 4$ and CYP2D6 by Indonesian medicinal plants. Journal of ethnopharmacology, 2006; 105(3): 449-455.

47. Noor $\mathrm{H}$, Hammonds $P$, Sutton R, Ashcroft SJH. The hypoglycaemic and insulinotropic activity of Tinospora crispa: studies with human and rat islets and HIT-T15 B cells. Diabetologia, 1989; 32(6): 354-359.
48.

Sriyapai C, Dhumma-upakorn $R$, Sangwatanaroj $S$, Kongkathip N, Krittiyanunt S. Hypoglycemic effect of Tinospora crispa dry powder in outpatients with metabolic syndrome at King Chulalongkorn Memorial Hospital. Journal of Health Research, 2009; 23(3): 125-133.

49. Noipha K, Ninla-aesong P. The activation of GLUT1, AMPKa and PPARY by Tinospora crispa in L6 myotubes. Spatula DD, 2011; 1(4): 245-249. 